\title{
Austrolebias varzeae, a new annual fish from the upper rio Uruguay basin, southern Brazil (Cyprinodontiformes: Rivulidae)
}

\author{
Wilson J. E. M. Costa*, Roberto E. Reis** and Everton R. Behr***
}

Austrolebias varzeae n. sp. is described from rio da Várzea floodplains, upper rio Uruguay basin, southern Brazil. It seems to be closely related to $A$. carvalhoi (Myers), with which it shares a similar color pattern of male and an apomorphic morphology of the autopalatine. The new species differs from A. carvalhoi by having more anal-fin rays in males and more caudal-fin rays. Austrolebias varzeae is distinguished from all other species of the genus by a unique color pattern, in which there are three distinctively darker and narrower bars on the anterior portion of male flank. Putative close relationships between A. varzeae and A. carvalhoi suggest a closely related biogeographic history between upper Uruguay and upper Iguaçu River basins, corroborated by a biogeographic pattern of the anablepid genus Jenynsia.

Austrolebias varzeae sp. n. é descrita da várzea do rio da Várzea, bacia do rio Uruguai superior, sul do Brasil. Ela parece estar estreitamente aparentada a A. carvalhoi, com a qual compartilha um padrão de colorido similar e uma morfologia apomórfica do autopalatino. A nova espécie difere de A. carvalhoi por possuir mais raios na nadadeira anal de machos e mais raios na nadadeira caudal. Austrolebias varzeae se distingue de todas as espécies do gênero por um padrão de colorido exclusivo, no qual há três barras distintivamente mais estreitas e mais escuras na porção anterior do flanco do macho. As supostas estreitas relações de parentesco entre $A$. varzeae e A. carvalhoi sugerem uma história biogeográfica intimamente relacionada entre as bacias do rio Uruguai e do rio Iguaçu superiores, corroborada por um padrão biogeográfico do gênero anablepídeo Jenynsia.

Key words: New species, killifishes, systematics, Neotropical.

\section{Introduction}

Austrolebias Costa was recently established to name a monophyletic assemblage of annual fishes endemic to northern and northeastern Argentina, Paraguay, southern Brazil, and Uruguay (Costa, 1998a). This genus is diagnosed by three synapomorphies: (1) basihyal cartilage more than $50 \%$ of basihyal lenght; (2) dorsal fin positioned anteriorly, origin at vertical between neural spines of vertebrae 7 and 10; and (3) female color pattern consisting of vertical rows of dark spots on flank (Costa, 2002). Austrolebias comprises a total of 24 valid species, which inhabit temporary lagoons along floodplains of the middle and lower sections of the Paraguay, Parana, and Uruguay River basins, and the laguna dos Patos system (Costa, 1998a, 2002; Costa \& Cheffe, 2001). One exception is A. carvalhoi (Myers), found in the highlands of the upper rio Iguaçu floodplains, southern Brazil (Costa, 1998b). The new species herein described, was collected in another highland area, the upper rio Uruguay basin.

\footnotetext{
* Laboratório de Ictiologia Geral e Aplicada, Departamento de Zoologia, Universidade Federal do Rio de Janeiro, Caixa Postal 68049, 21944-970 Rio de Janeiro, RJ, Brazil. e-mail: wcosta@acd.ufrj.br

** Laboratório de Ictiologia, Pontifícia Universidade Católica do Rio Grande do Sul, Caixa Postal 1429, 90619-900 Porto Alegre, RS, Brazil. e-mail: reis@pucrs.br

*** Programa de Pós-Graduação em Zoologia, Pontifícia Universidade Católica do Rio Grande do Sul, Caixa Postal 1429, 90619-900 Porto Alegre, RS, Brazil. e-mail: everton_behr@hotmail.com
} 


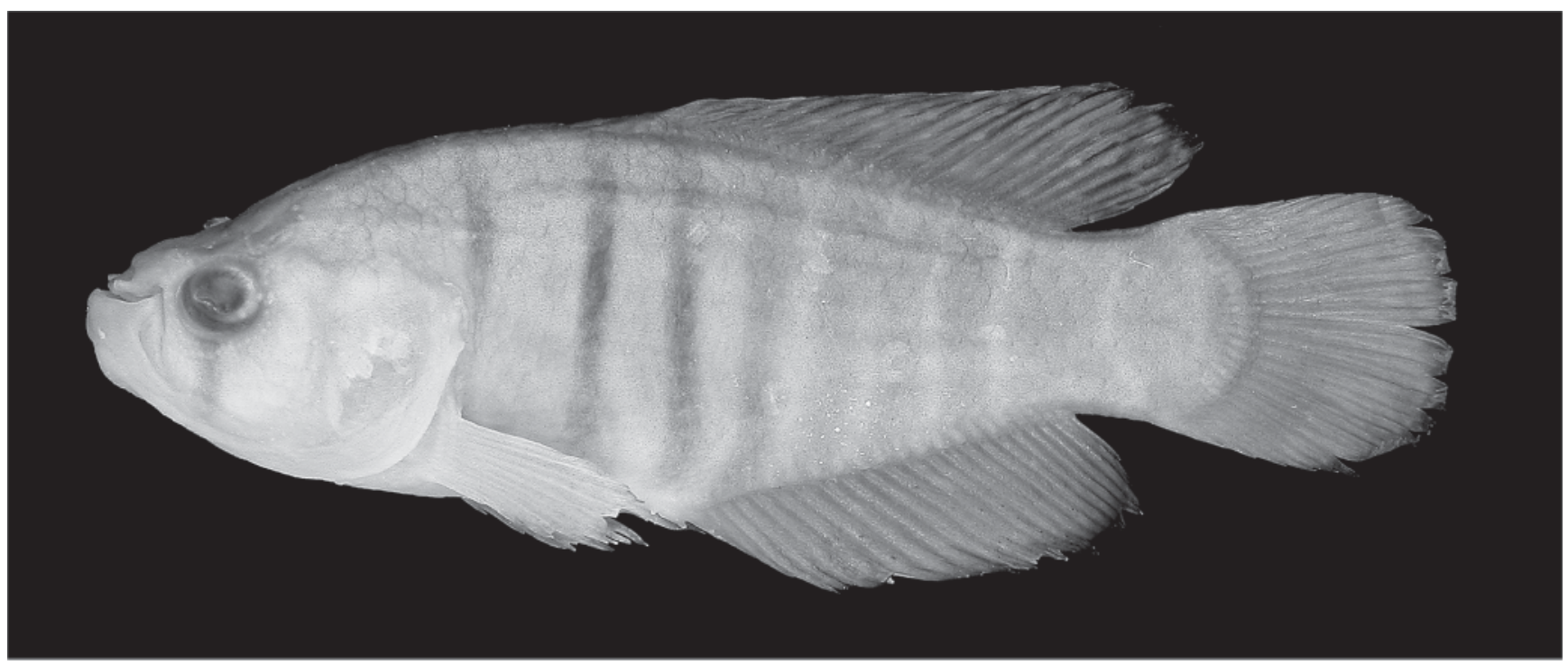

Fig. 1. Austrolebias varzeae, holotype, MCP 29641, male, $33.7 \mathrm{~mm} \mathrm{SL}$; temporary lagoon close to the rio da Várzea, rio Uruguay basin, Carazinho, Rio Grande do Sul, Brazil.

\section{Material and Methods}

Measurements and counts are according to Costa (1995). All measurements are presented as percentages of standard length (SL). Counts of pelvic, pectoral, and caudal fin-rays and vertebrae were made only on cleared and counterstained specimens (c\&s) prepared according to Taylor \& Van Dyke (1985). The compound caudal centrum was counted as a single element in vertebrae numbers. Nomenclature for frontal squamation follows Hoedeman (1958) and terminology for cephalic neuromasts is according to Costa (2001). Selected osteological character states included in the description are those with some phylogenetic importance according to Costa (2002). Specimens examined of Austrolebias carvalhoi (9 specimens) are listed in Costa (1998b). Abbreviations for institutions are: MCP, Museu de Ciências e Tecnologia da Pontifícia Universidade Católica do Rio Grande do Sul, Porto Alegre, and UFRJ, Universidade Federal do Rio de Janeiro, Rio de Janeiro.

\section{Austrolebias varzeae, new species}

\section{Fig. 1}

Holotype. MCP 29641, male, 33.7 mm SL; Brazil: Rio Grande do Sul, temporary lagoon close to the rio da Várzea, Fazenda dos Branda, Carazinho, rio Uruguay basin, approximately $28^{\circ} 18^{\prime} \mathrm{S}$, 52²8’W; M. N. Xavier, 26 Aug 1999.

Paratypes. MCP 23667, 7 males (1 c\&s), 23.8-32.5 mm SL, and 2 females, 24.8-25.3 mm SL; UFRJ 5431, 1 male, 30.9 mm SL, and 1 female, $25.8 \mathrm{~mm} \mathrm{SL}$; UFRJ 5432, 1 male, $31.9 \mathrm{~mm} \mathrm{SL}$, and 1 female (c\&s), $23.5 \mathrm{~mm}$ SL; all collected with holotype.

Diagnosis. Readily distinguished from all congeners by a unique color pattern of male, consisting of dark gray bars on flank, the three anteriormost bars distinctively darker and narrower than posterior ones (Fig. 1). It is similar to $A$. carvalhoi and distinguished from all other species of the genus by the combination of pattern of bars on male flank and autopalatine with a prominent dorsomedial projection. It differs from $A$. carvalhoi by having more anal-fin rays in male (23-26 vs. 21-22) and consequently a longer anal-fin base length (38.1-40.9\% SL vs. 31.4-35.1\% SL), and more caudalfin rays (28-29 vs. 25-26). Other features plesiomorphic for Austrolebias but useful to distinguish A. varzeae are the urogenital papilla of male not attached to anal fin, pelvic fins not united medially, 22-24 dorsal-fin rays in male and 16-18 in female, 18-19 anal-fin rays in female, and 28-30 scales in the longitudinal series.

Description. Morphometric data for holotype and seven paratypes given in Table 1. Male larger than female, reaching at least $33.7 \mathrm{~mm} \mathrm{SL}$. Dorsal profile concave on head, convex between snout and end of dorsal-fin base, approximately straight on caudal peduncle. Ventral profile convex from lower jaw to end of anal-fin base, nearly straight on caudal peduncle. Longest body depth on vertical through dorsalfin origin. Body somewhat deep, compressed, body depth approximately 1.9 times body width in larger males. Snout blunt, jaw short.

Tip of dorsal and anal fins rounded. Anteromedian rays of anal fin of female not lengthened, anal fin shape approximately semicircular. Urogenital papilla of male not attached to anal fin. Caudal fin rounded. Pectoral fin elliptical, its posterior margin reaching vertical between pelvic-fin base and urogenital papilla in male, and reaching vertical through urogenital papilla in female. Tip of pelvic fin reaches base of second anal-fin ray. Pelvic-fin bases in close proximity, but fins not medially united. Dorsal-fin origin approximately on vertical through pelvic-fin base in male, and through 
urogenital papilla in female. Anal-fin origin on vertical through base of second or third dorsal-fin ray. Dorsal-fin rays 22-24 in male, 16-18 in female; anal-fin rays 23-26 in male, 18-19 in female; caudal-fin rays 28-29; pectoral-fin rays 12 ; pelvic-fin rays 5 .

Scales large, cycloid. Body and head entirely scaled, except on ventral surface of head. Frontal squamation Fpatterned. No transverse row of scales on anal-fin base. Pectoral-fin base naked. Longitudinal series of scales 28-30, transverse series of scales 16-17, and scale rows around caudal peduncle 20. One discrete ctenii-like contact organ on each scale of ventral portion of body side of male. No contact organs on unpaired fins and outer surface of pectoral and pelvic fins. Rudimentary papillate contact organs on inner surface of three dorsalmost rays of pectoral-fin of male. Supraorbital neuromasts 15-22.

Jaw teeth gently bowed, with few larger fang-like teeth laterally. Slight concavity on anteromedial portion of premaxilla. Alveolar arm of premaxilla with prominent anterior process. Prominent rounded dorsomedial projection on autopalatine. Basihyal about triangular, its longest width about $80 \%$ of its total length; basihyal cartilage long, occupying about $65 \%$ of total basihyal length, and with pronounced lateral projections on its anterior portion. Anterior ceratohyal not elongated. Six branchiostegal rays. Urohyal deep. Three to five teeth on second pharyngobranchial. Gill-rakers on the first branchial arch 3+9. Lateral process of sphenotic narrow, without anterior expansion. Posterior arm of parasphenoid narrow. Lacrimal approximately straight in its dorsoventral axis. Dermosphenotic absent. Ventral process of posttemporal robust. Total vertebrae $27-28$.

Color in alcohol. Male: Side of body light yellowish brown with nine to 11 dark gray bars; first three bars darker and narrower than posterior ones, their width about half or less interspace width; posterior bars about twice wider than interspace. Head light yellowish brown, with dark gray suborbital bar and triangular dark gray spot posterodorsally adjacent to orbit. Unpaired fins dark gray with light gray dots. Pectoral fin hyaline. Pelvic fin dark gray (Fig. 1). Female: Side of body light yellowish brown, with dark gray rounded spots; spots of anterocentral portion of flank darker. Head light yellowish brown, with faint suborbital bar and faint triangular gray spot posterodorsally adjacent to orbit. Unpaired fins hyaline, with faint small gray spots on basal portion of anal fin.

Distribution. Known only from the type locality (Fig. 2).

Habitat notes. The type-specimens were collected in a temporary lagoon distant about $50 \mathrm{~m}$ from the rio da Várzea. The lagoon is shallow (maximum depth about $1.5 \mathrm{~m}$ ) and vegetation is composed mainly of grasses, Nymphaea sp., Ludwigia sp., and a large volume of filamentous algae. The lagoon is temporarily connected to the river during flooding, when other fishes as Astyanax and Oligosarcus species are also found in the lagoon.
Etymology. Austrolebias varzeae is named after the river basin were it was collected, the rio da Várzea.

\section{Discussion}

Austrolebias varzeae possesses a prominent rounded dorsomedial projection on the autopalatine, a condition also found in A. carvalhoi, A. nonoiuliensis (Taberner, Fernandez $\&$ Castelli), A. robustus (Güenther), A. cinereus (Amato), A. nioni (Berkenkamp, Reichert \& Prieto), and A. vazferrerai (Berkenkamp, Etzel, Reichert \& Salvia), which are hypothesized to be basal taxa within Austrolebias (Costa, 2002). That prominent projection of autopalatine is absent in all other species of Austrolebias, as well as in species of closely related genera such as Megalebias Costa and Cynolebias Steindachner (Costa, 2001; 2002), and thus interpreted as apomorphic. Among species of the above assemblage, $A$. varzeae is possibly more closely related to $A$. carvalhoi, with which it shares a similar male color pattern consisting of dark bars on body side. However, it is not clear if the color pattern shared by $A$. varzeae and $A$. carvalhoi is in fact an apomorphic condition, since bars on male flank are present in several other clades of cynolebiatines, including

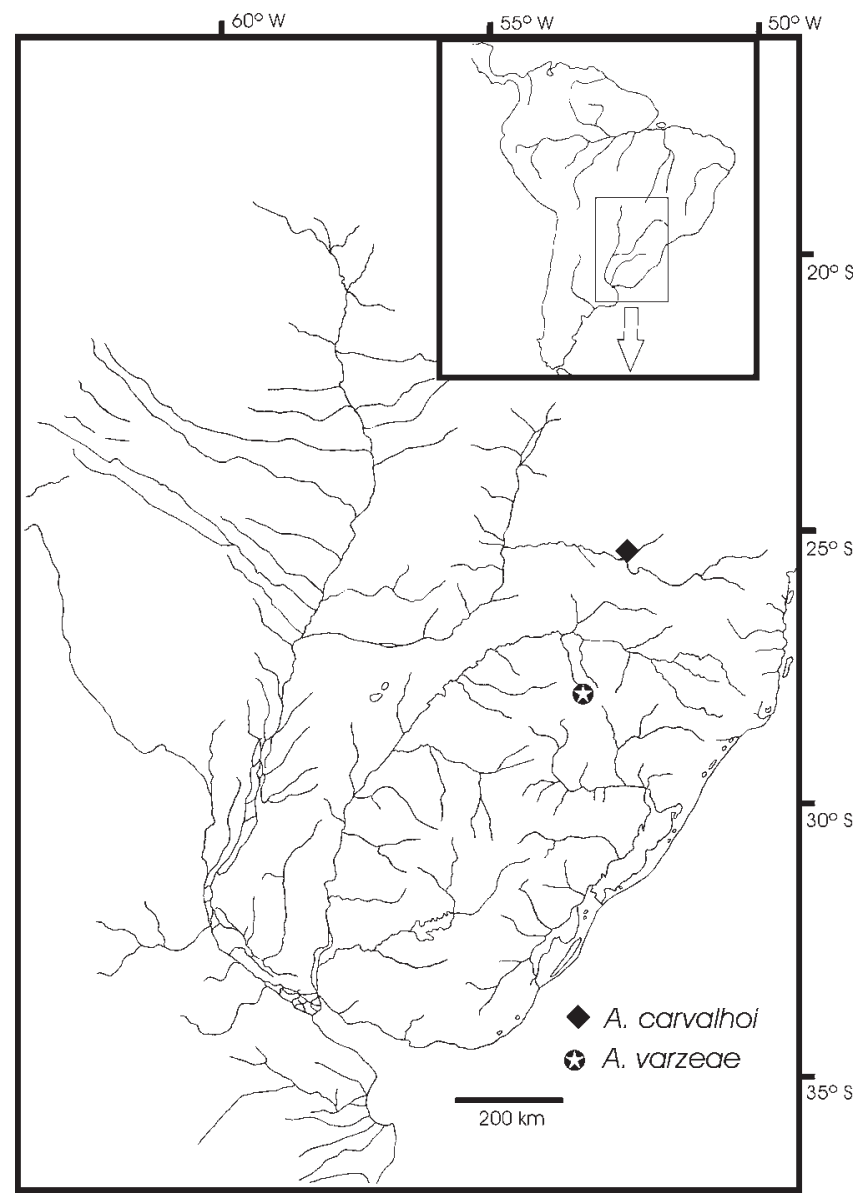

Fig. 2. Geographic distribution of Austrolebias carvalhoi and A. varzeae. 
Table 1. Morphometric data of holotype $(\mathrm{H})$ and seven paratypes of Austrolebias varzeae.

\begin{tabular}{|c|c|c|c|c|c|c|c|c|}
\hline & \multicolumn{5}{|c|}{ Males } & \multicolumn{3}{|c|}{ Females } \\
\hline & \multirow{3}{*}{$\begin{array}{l}\mathrm{H} \\
\text { MCP } \\
29641\end{array}$} & \multicolumn{7}{|c|}{ Paratypes } \\
\hline & & MCP & UFRJ & $\mathrm{MCP}$ & $\mathrm{MCP}$ & UFRJ & $\mathrm{MCP}$ & MCP \\
\hline & & 23667 & 5431 & 23667 & 23667 & 5431 & 23667 & 23667 \\
\hline Standard length $(\mathrm{mm})$ & 33.7 & 32.5 & 30.9 & 30.3 & 28.0 & 25.8 & 25.3 & 24.8 \\
\hline \multicolumn{9}{|l|}{ Percents of standard length } \\
\hline Body depth & 38.1 & 34.8 & 38.8 & 38.9 & 35.0 & 32.9 & 36.1 & 36.6 \\
\hline Caudal peduncle depth & 17.7 & 15.4 & 18.0 & 17.2 & 15.9 & 15.2 & 15.1 & 16.9 \\
\hline Predorsal length & 50.8 & 50.5 & 52.2 & 51.6 & 51.9 & 60.0 & 62.0 & 59.4 \\
\hline Prepelvic length & 52.1 & 52.8 & 55.1 & 53.8 & 52.9 & 57.6 & 54.9 & 57.8 \\
\hline Length of dorsal-fin base & 41.3 & 40.2 & 40.9 & 40.6 & 39.0 & 28.5 & 27.7 & 28.4 \\
\hline Length of anal-fin base & 39.7 & 38.1 & 40.9 & 40.0 & 39.7 & 25.7 & 23.2 & 23.0 \\
\hline Caudal-fin length & 32.3 & 29.8 & 34.8 & 31.1 & 31.6 & 31.4 & 35.1 & 33.8 \\
\hline Pectoral-fin length & 23.4 & 20.5 & 21.9 & 22.7 & 23.6 & 21.6 & 24.6 & 25.4 \\
\hline Pelvic-fin length & 8.2 & 8.8 & 10.9 & 9.5 & 8.7 & 9.9 & 10.7 & 10.8 \\
\hline Head length & 31.0 & 28.8 & 31.4 & 31.9 & 31.4 & 30.6 & 32.6 & 32.4 \\
\hline Head depth & 33.2 & 31.0 & 31.8 & 33.1 & 30.7 & 29.7 & 33.1 & 32.5 \\
\hline Head width & 20.3 & 19.8 & 21.8 & 20.1 & 19.9 & 19.7 & 21.5 & 22.2 \\
\hline Snout length & 5.0 & 4.2 & 5.1 & 5.2 & 4.5 & 4.9 & 4.4 & 4.6 \\
\hline Lower jaw length & 7.4 & 7.3 & 8.0 & 7.3 & 6.3 & 6.6 & 6.9 & 7.2 \\
\hline Eye diameter & 8.4 & 7.5 & 8.8 & 8.8 & 8.6 & 9.3 & 9.3 & 9.9 \\
\hline
\end{tabular}

Austrolebias, and may be plesiomorphic for cynolebiatines as discussed by Costa (2002). Other characters would be necessary to clarify the phylogenetic position of A. varzeae, including live color patterns that are important to diagnose species assemblages within Austrolebias (Costa, 2002), but are not available for $A$. varzeae at the present.

Finally, besides similarities in the general morphology and color pattern, A. varzeae and A. carvalhoi inhabit parallel neighbor river basins (upper Uruguay and Iguaçu Rivers, respectively; Fig. 2), in biotopes inserted at higher altitudes (600-800 m), also suggesting close affinities. All other species of the clade Austrolebias plus Megalebias occur along the floodplains of the Parana-Uruguay-Paraguay system at lower altitudes (until about $150 \mathrm{~m}$ ) or along coastal systems. Besides geographic proximity, a close biogeographic history among the upper Uruguay and upper Iguaçu basins has also been suggested in a recent phylogenetic study on another cyprinodontiform group. Within the anablepid genus Jenynsia Günther, which has a distribution pattern in much overlapping that of Austrolebias, J. eigenmanni (Haseman), endemic to the upper Iguaçu basin, is hypothesized to be the sister group to J. eirmostigma Ghedotti \& Weitzman, endemic to the upper rio Uruguay basin and adjacent areas (Ghedotti, 1998; Ghedotti et al. 2001).

\section{Acknowledgments}

We would like to express our gratitude to Marcelo de Negri Xavier, who collected the specimens used in this description and brought them to our attention, and to the family Branda for help during the collecting expeditions. RER would like to thank the Conselho de Desenvolvimento Científico e
Tecnológico (CNPq) (Process 305344-87) for support. The first author received financial support from CNPq and Fundação de Amparo à Pesquisa do Estado do Rio de Janeiro (FAPERJ).

\section{Literature cited}

Costa, W. J. E. M. 1995. Pearl killifishes - the Cynolebiatinae: systematics and biogeography of the neotropical annual fish subfamily. Neptune City, TFH, 128p.

Costa, W. J. E. M. 1998a. Phylogeny and classification of Rivulidae revisited: evolution of annualism and miniaturization in rivulid fishes (Cyprinodontiformes: Aplocheiloidei). Journal of Comparative Biology, 3(1):33-92.

Costa, W. J. E. M. 1998b. Rediscovery and redescription of Cynolebias carvalhoi (Cyprinodontiformes: Rivulidae). Ichthyological Exploration of Freshwaters, 9(3): 305-310.

Costa, W. J. E. M. 2001. The neotropical annual fish genus Cynolebias (Cyprinodontiformes: Rivulidae): phylogenetic relationships, taxonomic revision and biogeography. Ichthyological Exploration of Freshwaters, 12(4): 333-383.

Costa, W. J. E. M. 2002. Monophyly and phylogenetic relationships of the Neotropical annual fish genera Austrolebias and Megalebias (Cyprinodontiformes: Rivulidae). Copeia, 2002(4): 916-927.

Costa, W. J. E. M. \& M. M. Cheffe. 2001. Three new species of the genus Austrolebias from the laguna dos Patos system, southern Brazil, and a redescription of A. adloffi (Ahl) (Cyprinodontiformes: Rivulidae). Comunicações do Museu de Ciências e Tecnologia da PUCRS, Série Zoologia, 14(2): 179-200. 
Ghedotti, M. J. 1998. Phylogeny and classification of the Anablepidae (Teleostei: Cyprinodontiformes). Pp 561-582. In: Malabarba, L. R., R. E. Reis, R. P. Vari, Z. M. S. Lucena $\&$ C.A.S. Lucena (Eds.). Phylogeny and classification of neotropical fishes. Porto Alegre, Edipucrs, 603p.

Ghedotti, M. J., A. D. Meisner \& P. H. F. Lucinda. 2001. New species of Jenynsia (Teleostei: Cyprinodontiformes) from southern Brazil and its phylogenetic relationships. Copeia, 2001(3): 726-736.
Hoedeman, J. J. 1958. Rivulid fishes of the Antilles. Studies on the Fauna of Curaçao and other Caribbean Islands, 32: 112-127.

Taylor, W. R. \& G. C. Van Dyke. 1985. Revised procedures for staining and clearing small fishes and other vertebrates for bone and cartilage study. Cybium, 9: 107-109.

Received April, 2004 Accepted April, 2004 